\title{
Interimplant Papilla Reconstruction
}

\author{
${ }^{1}$ Sneha Anil Rajguru, ${ }^{2}$ Tushar Sakal Pathak, ${ }^{3}$ Ashvini Mukul Padhye, ${ }^{4}$ Sachin Kanagotagi \\ ${ }^{5}$ Himani Swatantrakumar Gupta, ${ }^{6}$ Aditi Ashok Rathod
}

\begin{abstract}
Background and objective: Pink gingival esthetics, especially in the anterior teeth, has been an important success criterion in implant-supported restoration. The factor vital to the esthetic success, in the anterior maxillary implants, is the soft tissue profile, which should replicate that of the natural healthy tooth. The absence of the interimplant papilla causes an interimplant black triangle thus leading to cosmetic deformities, phonetic difficulty and food impaction. True papilla regeneration is not possible because the peri-implant soft tissue does not have the same structure as that of the periodontium and, therefore, the term 'papilla-like' tissue formation or 'implant papilla' is used. This resultant 'implant papilla' is the product of soft tissue depth and volume and has to be skilfully surgically created. However, reconstructing a predictable peri-implant papilla is the most complex and challenging aspect of implant dentistry. This article presents a review of various innovative surgical techniques to reconstruct interimplant papilla.
\end{abstract}

Keywords: Interimplant papilla, Esthetics, Implant surgery, Peri-implant plastic.

How to cite this article: Rajguru SA, Pathak TS, Padhye AM, Kanagotagi S, Gupta HS, Rathod AA. Interimplant Papilla Reconstruction. J Contemp Dent 2014;4(1):30-40.

Source of support: Nil

Conflict of interest: None

\section{INTRODUCTION}

Peri-implant plastic surgery is defined as "harmonizing the peri-implant structures by means of hard and soft tissue engineering and includes bone structure enhancement, soft tissue enhancement, precision in implant placement; and quality of the prosthetic restoration'. ${ }^{1}$ The rationale is to create peri-implant keratinized mucosa and interimplant soft tissue height in order to avoid food impaction, interimplant airflow and speech problems. ${ }^{1}$

The pink gingival esthetics, especially in the anterior teeth, has been an important success criterion in implantsupported restoration. The factor vital to the esthetic success in the anterior maxillary implants, is the soft tissue profile, which should replicate that of the natural healthy tooth.

\footnotetext{
${ }^{1,6}$ Postgraduate Student, ${ }^{2,4,5}$ Senior Lecturer

${ }^{3}$ Professor and Head

${ }^{1-6}$ Department of Periodontics, MGM Dental College and Hospital, Navi Mumbai, Maharashtra, India
}

Corresponding Author: Sneha Anil Rajguru, Postgraduate Student, Department of Periodontics, MGM Dental College and Hospital, Navi Mumbai, Maharashtra, India, Phone: 02227426604, e-mail: drsneharajguru@gmail.com
The peri-implant mucosal height follows the crest of the alveolar bone; however, the determining factors in interimplant papilla development are complex and may not be fully controlled by implant design features or surgical interventions. ${ }^{1}$ Although bone height and thickness are major determinants of soft tissue height, factors, such as tooth morphology, location of the interdental contact point, and arrangement and quality of soft tissue fibers can also influence soft tissue appearance.

Since there is a lack of dento-gingivo-alveolar, circular, semicircular, transeptal, interpapillary and intergingival fibers around implants, true papilla regeneration is not possible and, therefore, the term 'papilla-like' tissue formation or 'implant papilla' is used. ${ }^{2}$ This resultant 'implant papilla' is the product of soft tissue depth and volume and has to be skilfully surgically created. The absence of the interimplant papilla causes an interimplant 'black triangle' thus leading to cosmetic deformities, phonetic difficulty and food impaction.

This article reviews the anatomic features that influence the outcome of dental implant therapy and presents a range of innovative surgical modalities to reconstruct the peri-implant papilla that aims at enhancing the esthetic appearance of peri-implant soft tissue.

\section{HISTORY}

The origin of the word papilla is from Latin word 'papula', which a small projecting body part similar to a nipple in form. Morphologically, the interdental papillae had been first described by Cohen in 1959. ${ }^{3}$ Bergstrom in 1984 defined the papillary gingiva as the gingival surface contained between lateral and central incisors, extending from the incisal tip of the papilla to a line tangent to the gingival margin of the two incisor crowns. ${ }^{4}$ Patients have come to expect esthetically pleasing restorative treatments and have questioned the disappearance of interdental papilla, so-called 'black triangles disease'. Several techniques have been proposed to reconstruct the lost interdental papilla. In 1985, Shapiro proposed a noninvasive approach to recreate papillae destroyed after acute necrotizing ulcerative gingivitis. He induced proliferation of gingival tissue by inflammatory hyperplasia produced after repeated scaling, root planing and curettage. ${ }^{5}$ Beagle ${ }^{6}$ suggested a combination flap using the basic principles of the Abrams roll technique for ridge 
augmentation $^{7}$ and the papilla preservation technique of Evian et al. ${ }^{8}$ Use of free soft tissue grafts for papillary augmentation was first proposed by Han and Takei in 1996. ${ }^{9}$ They described a semilunar incision with coronal displacement of the gingivopapillary unit and placement of a subgingival connective tissue graft. But the semilunar coronally repositioned papilla, similar to the procedure reported by Tarnow, appears to be the most predictable procedure at the present time due to the movement of a large segment of gingival-papillary unit with intact blood supply. ${ }^{10}$ In case of surgical management of the lost interimplant papilla, it was Palacci in 1995 who first described the technique in order to restore the papilla around implants with semilunar bevelled incision is performed in relation to each implant that is rotated $90^{\circ}$ toward the mesial aspect of the abutment and stabilized with interrupted sutures. ${ }^{1}$ Since then, numerous studies have attempted ways to regenerate it papilla around the implants.

\section{CLASSIFICATION}

In order to guide the clinicians to deal with the difficulties of implant treatment, Palacci and Ericsson in 2001 proposed a classification system, which helps the practitioner to assess the pre-implant anatomical site. This system divides maxilla into four classes according to vertical (Figs 1 to 4 ) and horizontal (Figs 5 to 8 ) dimensions of tissue loss. ${ }^{1}$

Combinations of the different classes can also exist. For example, Class I-A, Class II-B, Class III-C, Class IV-D. The most important category of soft tissue loss in which attempts could be made in order to surgically restore a papilla-like tissue in between the implants is Class II-B. The manipulation of the peri-implant tissue can be carried out in order to replicate the soft tissue contours similar to

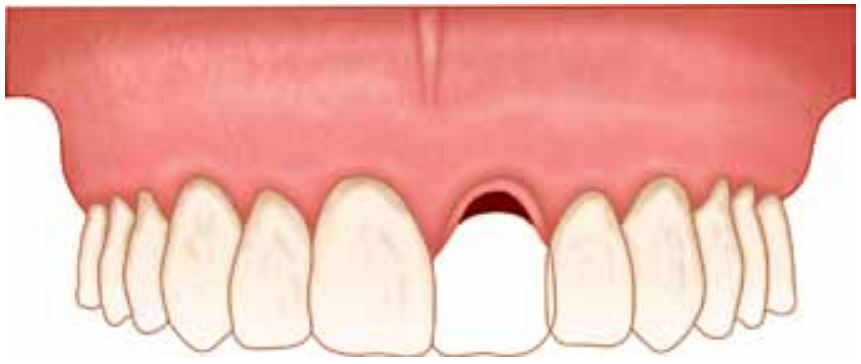

Fig. 1: Class I: Intact or slightly reduced papillae

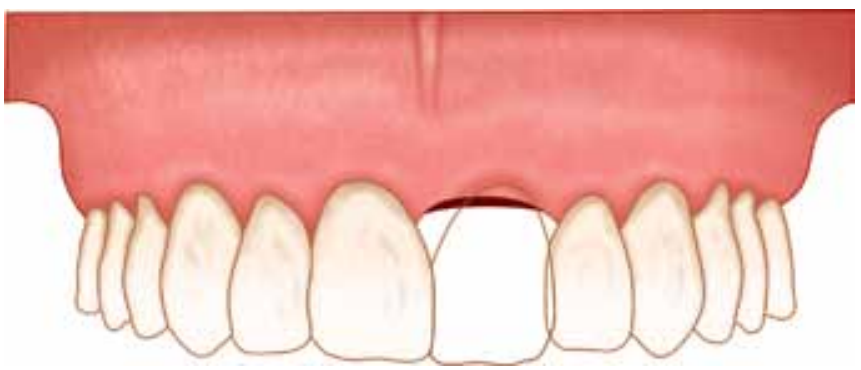

Fig. 2: Class II: Limited loss of papillae (less than $50 \%$ ) the healthy gingival anatomy around the teeth. There are various surgical techniques described to restore the periimplant papilla at the time of second-stage implant surgery.

\section{ANATOMY OF THE INTERIMPLANT PAPILLA}

The interdental papilla occupies the space above the alveolar crest interdentally. Among the maxillary anterior teeth, the papilla is located immediately beneath the contact point, i.e. in the incisal third (Fig. 9A). Therefore, it is the most visible structure since it fills the greatest space than others; hence, its lack causes major esthetic problems. Kokich observed that the gingival space larger than $3 \mathrm{~mm}$ is considered a visible esthetic problem both for the dentists and the general population. ${ }^{11}$ Therefore, the reconstruction of this papilla is most difficult to achieve. ${ }^{11}$

In case of the implants, the connective tissue fibers are oriented parallel to the implant surface and most of the gingivodental and transseptal fibers do not exist. The blood supply to the peri-implant mucosa is restricted due to the absence of the periodontal ligament and associated blood vessel branches. The blood supply to the peri-implant mucosa is provided by the branches from the bone and oral soft tissues. Also, there is presence of high amount of collagen and low amount of fibroblast; therefore, the periimplant mucosa can also be defined as 'scar-like tissues' (Fig. 9B). ${ }^{2}$

\section{FACTORS INFLUENCE THE PRESENCE OF INTERDENTAL/INTERIMPLANT PAPILLA}

\section{Availability of Underlying Osseous Support}

The foundation for the gingival support is the underlying contour of the osseous crest. Although the biologic width,

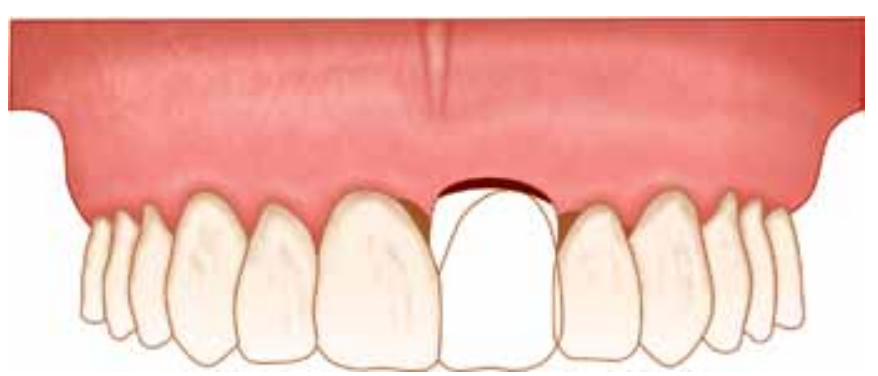

Fig. 3: Class III: Severe loss of papillae

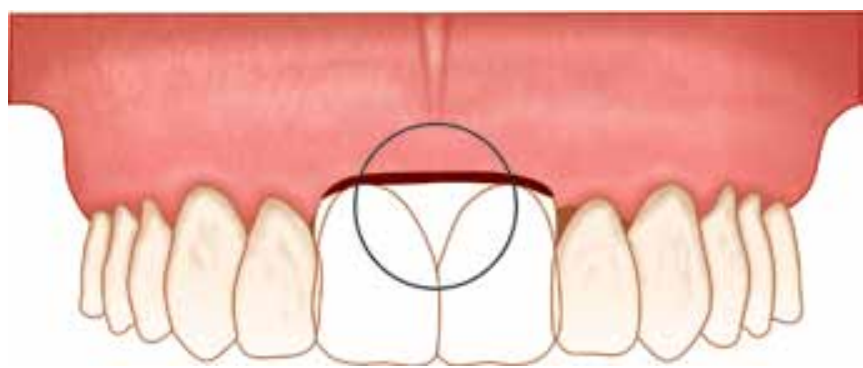

Fig. 4: Class IV: Absence of papillae (edentulous ridge) 


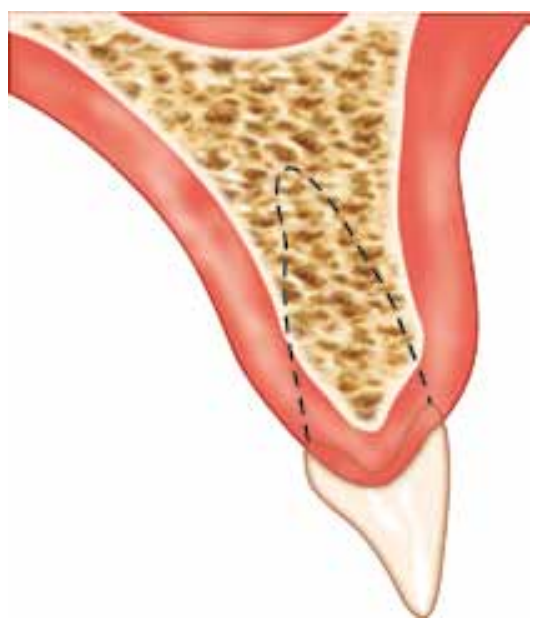

Fig. 5: Class A: Intact or slightly reduced buccal tissues

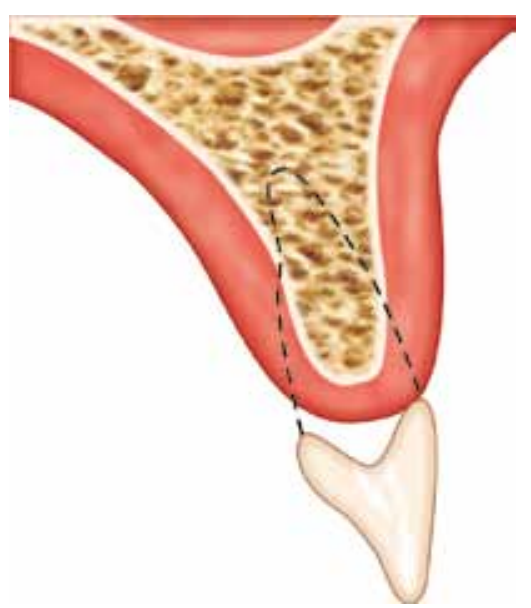

Fig. 6: Class B: Limited loss of buccal tissues

interproximally is similar to facial surface, the dentogingival complex is not (Gargiulo and colleagues, 1961; Vacek and colleagues, 1994). ${ }^{12}$ Kois (1994) and Spear (1999) pointed out that the dentogingival complex is $3.0 \mathrm{~mm}$ facially and 4.5 to $5.5 \mathrm{~mm}$ interproximally which can be explained partially by the increased scalloping of the bone. Spear suggested that the additional 1.5 to $2.5 \mathrm{~mm}$ of interproximal gingival tissue height requires the presence of adjacent teeth for maintainance of interproximal gingival volume. Without the presence of adjacent teeth, the interproximal tissue would flatten out, assuming a normal $3.0 \mathrm{~mm}$ biologic width with the underlying bone scallop, and esthetics would be compromised. ${ }^{12}$

\section{Biologic Width Around Implants}

The biologic width around implants is approximately $3 \mathrm{~mm}$ as compared to the natural tooth which is $2 \mathrm{~mm}$. There always exists a microgap between the implant and the abutment and the biologic width is formed apical to the implants. ${ }^{2}$ This leads to the crestal bone loss of around $2 \mathrm{~mm}$ irrespective

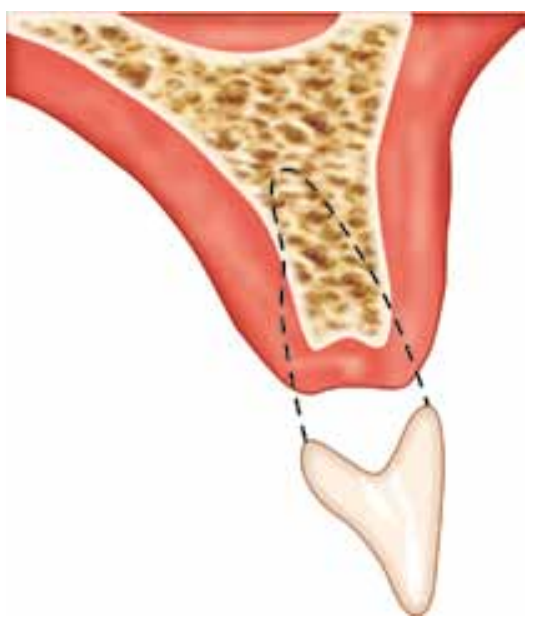

Fig. 7: Class C: Severe loss of buccal tissues

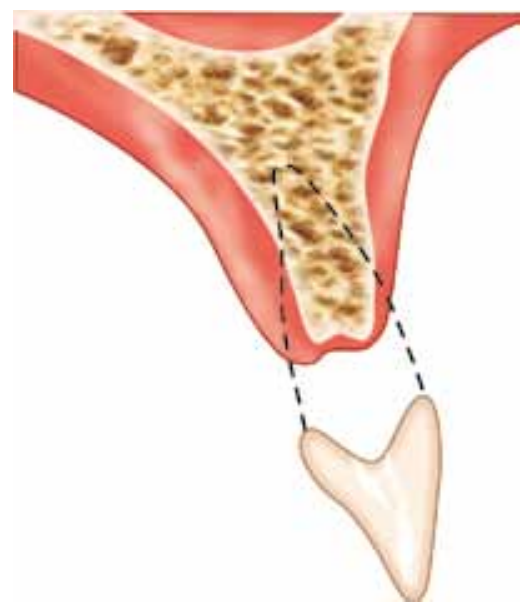

Fig. 8: Class D: Extreme loss of buccal tissue with limited amount of attached mucosa

of whether the microgap is located at or below the alveolar crest. Hence, the crestal bone loss is not dependant on the surgical technique (submerged or non-submerged) but on the location of the interface. ${ }^{2}$ When an implant is placed adjacent to the natural tooth, the implant abutment junction must be placed $4 \mathrm{~mm}$ apical to the labiogingival margin to create an esthetically pleasing gingival profile. ${ }^{2}$ This leads to the placement of the biologic width subcrestally. When two implants are placed adjacent to each other, there is loss of interproximal bone mainly due to the flat interproximal bone contour causing loss of interimplant papilla. ${ }^{2}$

\section{Soft Tissue Assessment}

The gingival scallop has been defined as flat, scalloped and pronounced according to the osseous anatomy (Becker et al 1997). ${ }^{3}$ Kois (2001) described the gingival biotype as being thick or thin. A thick gingival biotype implies more fibrotic tissue, more vascularization and thicker underlying hard tissue which in turn is more resistant to recession and often results in pocket formation in the presence of the 


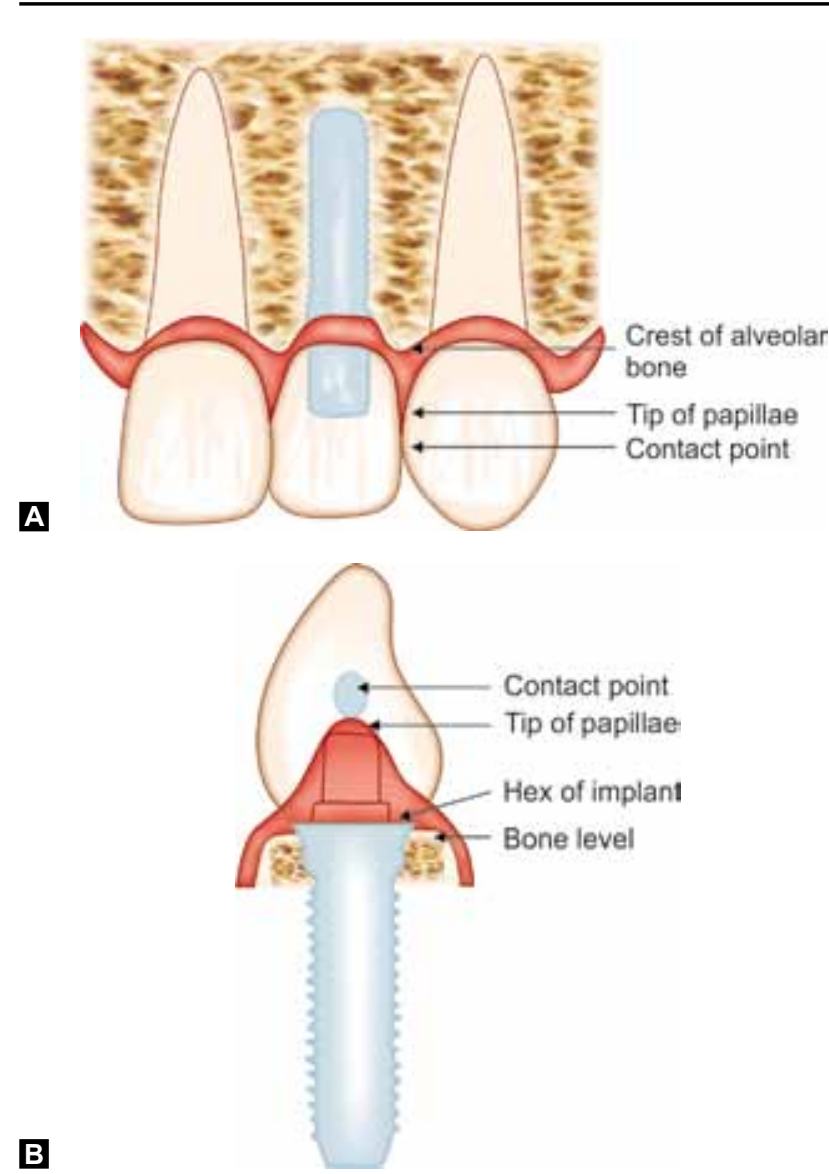

Figs $9 \mathrm{~A}$ and $\mathrm{B}$ : Interimplant papilla

bacterial insult. Thin gingival tissue has less underlying osseous support and less blood supply, which predisposes to recession after tooth extraction (Kois 2001). Highly scalloped cases with a friable gingiva require careful, atraumatic tooth extraction and flapless implant placement, which is advantageous because it minimizes bone loss and gingival recession (Garber et al 2001). This approach, however, is quite challenging because of lack of visibility and the possible existence of a thin labial plate of bone. ${ }^{3}$

\section{Hard Tissue Assessment}

Maintenance of the facial bone is equally important, in order to prevent future dehiscences and recession around implants. The teeth which are labially placed will present a very thin or no buccal cortical plate which will lead to a collapse of the gingival architecture and hence in such compromised situations, it may be optimal to extract the hopeless tooth, perform hard- and soft-tissue grafting and place the implant 3 to 6 months later. ${ }^{3}$ Spray et al (2000) examined the relationship between the amount of vertical bone loss and facial bone thickness and proposed the term of 'critical bone thickness' representing the facial plate thickness at which chances of bone gain or bone loss are minimal. ${ }^{3}$ The largest chances for bone resorption were observed when the facial thickness was less than $1.4 \mathrm{~mm}$, while the possibility of bone gain was seen at a $2 \mathrm{~mm}$ thickness. This is why the authors concluded that $2 \mathrm{~mm}$ is a critical thickness for the integrity of facial plate after stage 2 .

\section{SURGICAL TECHNIQUES TO RESTORE PERI-IMPLANT PAPILLA}

Currently, there is no predictable surgical procedure to retrieve the interdental papilla around implants, but a variety of surgical techniques are proposed by authors in order to create the interimplant papilla structure.

\section{Technique by Palacci (1995) ${ }^{1}$}

In this technique, semilunar incisions were made in the flap at each implant (Fig. 10A). The first one started distal to the most mesial implant. The tissue was then rotated toward the palate to create a papilla between the implant and the tooth (Fig. 10B). Semilunar incisions were also made more distally around each abutment. The rotation of the pedicles made it possible to close the space between the abutments (see Fig. 10B). Mattress sutures were used to hold the tissues in place (Fig. 10C). After postoperative healing, desired papilla was noticed in between the implants (Fig. 10D).

\section{Technique by Nemcovsky et al (2000) ${ }^{13}$}

A U-shaped incision with divergent arms open toward the buccal aspect of the implant site performed (Fig. 11A). The adjacent papillae remain adhered to the proximal teeth. Both sides of the incisions are palatally connected at approximately the palatal aspect of the implant cover-screw. The outer edges of the incisions and approximal papillae are de-epithelized (Fig. 11B). A full thickness flap is raised, and a healing abutment is placed. The flap is split in the center through its whole thickness, separating into the mesial and distal parts (Fig. 11C). Each part of the buccal flap is positioned over and de-epithelized papillae and secured to the palatal mucosa with vertical mattress suture (Fig. 11D).

\section{Technique by EI Salam EI Askary (2000) ${ }^{14}$}

A prefabricated custom-made titanium papillary insert can be used to support the interimplant papilla. It is pyramidshaped titanium core, which has height of 2 to $3 \mathrm{~mm}$ and a base that is $3 \mathrm{~mm}$ buccolingually and $1 \mathrm{~mm}$ in the mesiodistal dimension. It has also mesial and distal concavities to allow for the emergence of implant-supported prosthesis. It is fitted into the bone between two adjacent dental implants by means of self-tapping screws that are $0.8 \mathrm{~mm}$ in diameter and $5 \mathrm{~mm}$ in length. It creates a hard metal support for the tissue instead of bone. Soft tissue closure is achieved through relaxing incisions (Figs 12A and B).

\section{Technique by Grossberg (2001) ${ }^{\mathbf{1 5}}$}

A horizontal incision is made on the palatal aspect of the crest of ridge and along the palatal gingival margin vertical 
releasing incisions are placed so that interdental papilla is not included in the incision. Full thickness buccal and palatal flap are elevated to expose the underlying fixtures (Fig. 13A). The buccal flap is modified by creating a midline double pedicle flap (Fig. 13B), which is then mobilized to mesial and distal aspects of the implant and stabilized with sutures (Fig. 13C).

\section{Technique given by Azzi (2002) ${ }^{16}$}

This technique is useful in cases where there is no keratinized attached gingiva (Fig. 14A). The buccal flap is released from its insertion to the bone beyond the mucogingival junction

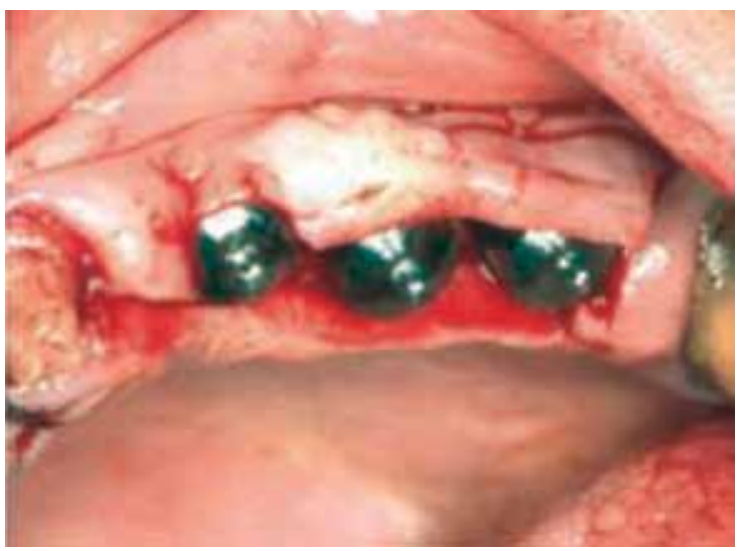

Fig. 10A: Semilunar incisions given in the flap

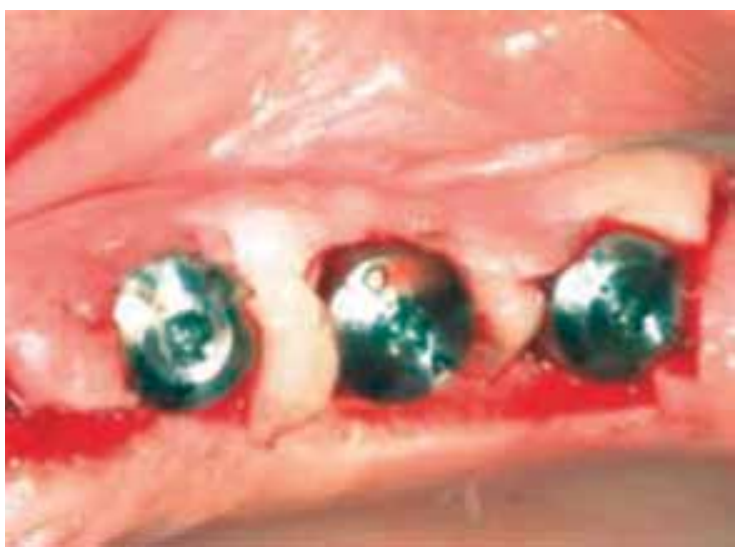

Fig. 10B: The tissue rotated toward the palate to create a papilla between the implant and the tooth

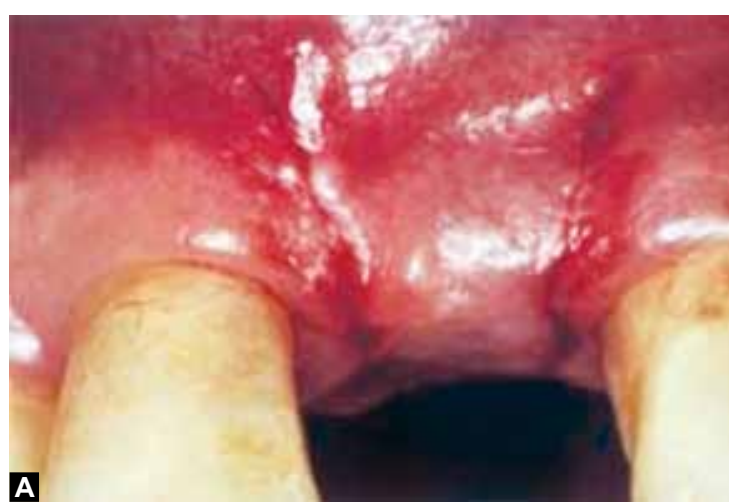

Figs 11A and B: A U-shaped incision with divergent arms opens toward the buccal aspect
(Fig. 14B). Papillae are undermined and the connective tissue graft is inserted into the pouch-like tunnel and completely submerged beneath the buccal flap and papillae. The flap is coronally advanced (Fig. 14C). Postoperative healing shows satisfactory results (Fig. 14D).

\section{Interimplant Regenerative Template ${ }^{17}$}

The interimplant papilla regenerative template is a carrier fabricated from pure titanium which acts as a housing that supports the bone-grafting material on the alveolar ridge, and it is placed between two implants to regenerate an osseous foundation for the interimplant papilla (Fig. 15A). The use

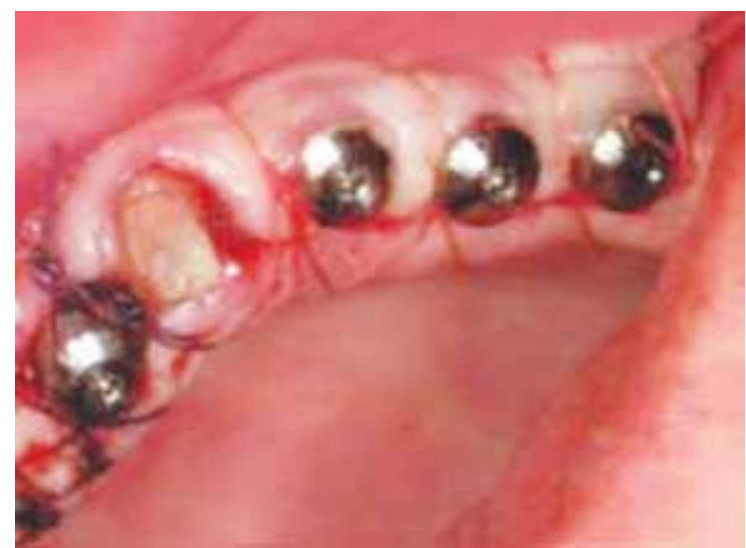

Fig. 10C: Mattress sutures given to hold the tissues in place

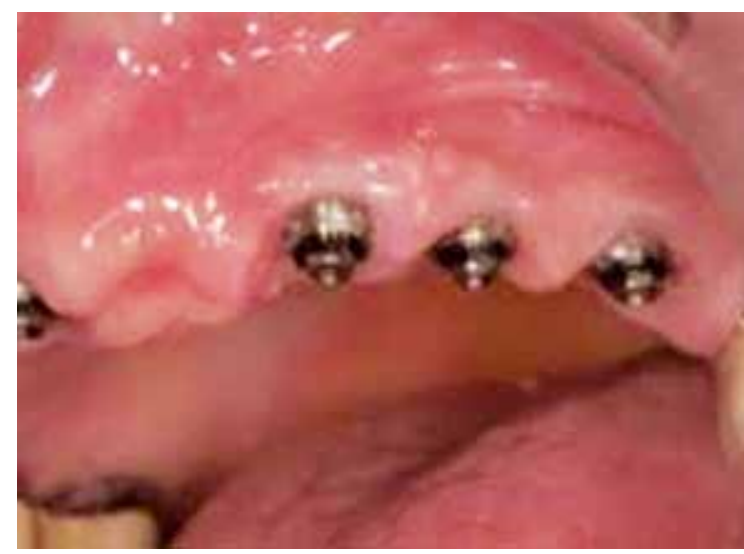

Fig. 10D: The desired papilla noticed in between the implants

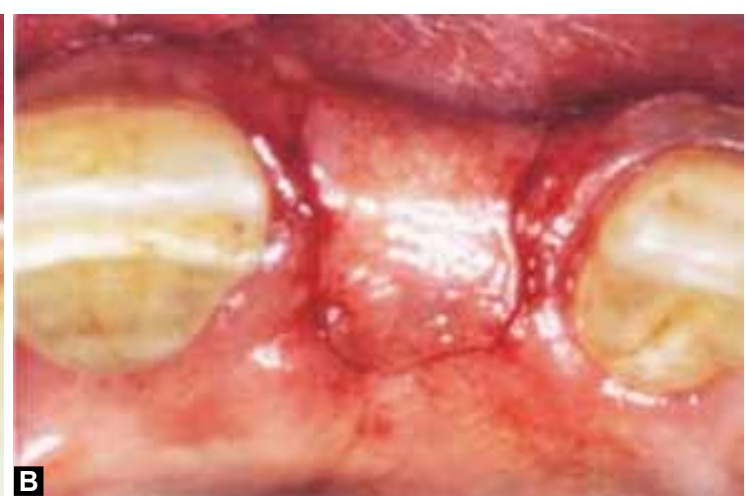




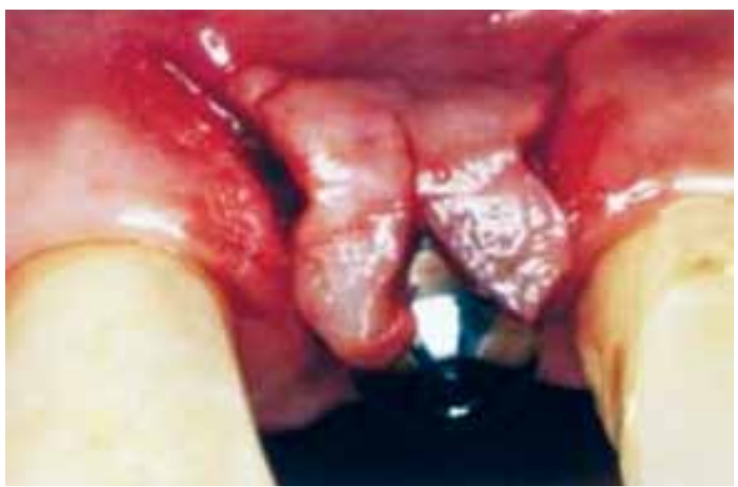

Fig. 11C : The flap is split in the center through its whole thickness, separating into the mesial and distal parts

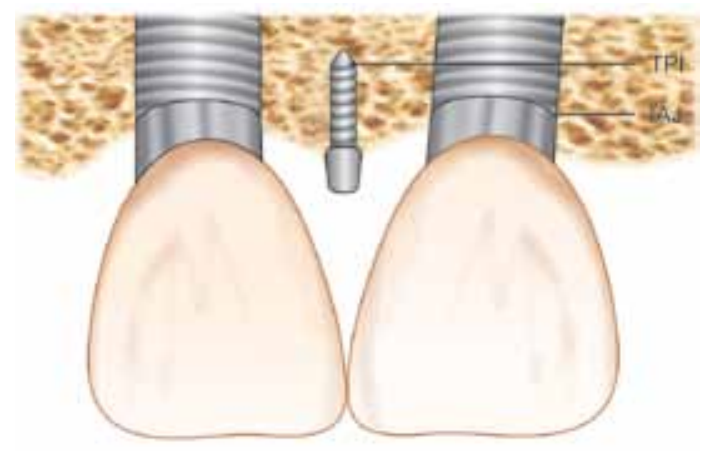

Fig. 12A: A prefabricated custom-made titanium papillary insert (TPI) is fitted in the bone between two implants

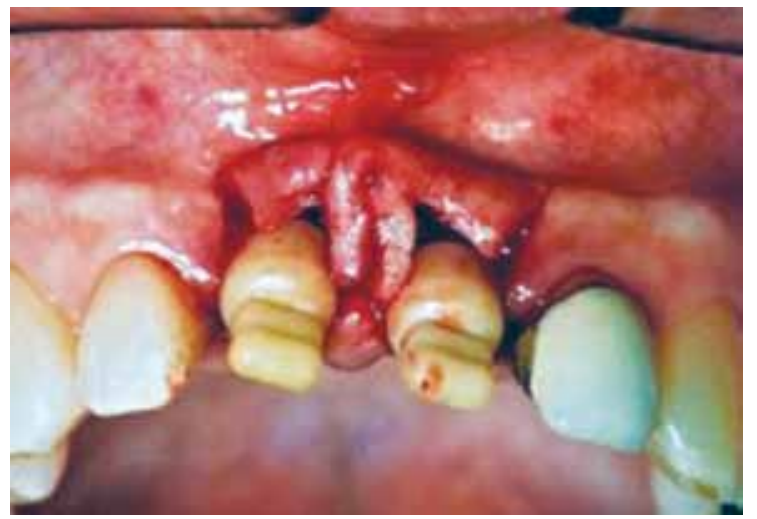

Fig.13A: Full thickness buccal and palatal flap are elevated to expose the underlying fixtures

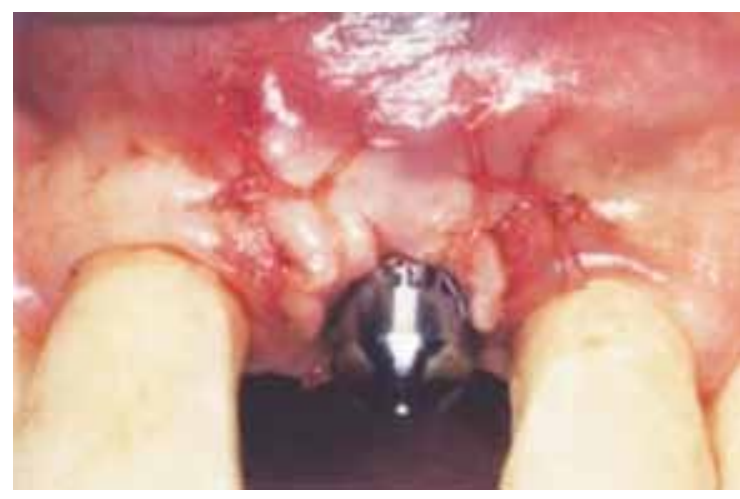

Fig. 11D: Each part of buccal flap is positioned over and de-epithelized papillae and secured to the palatal mucosa with vertical mattress suture

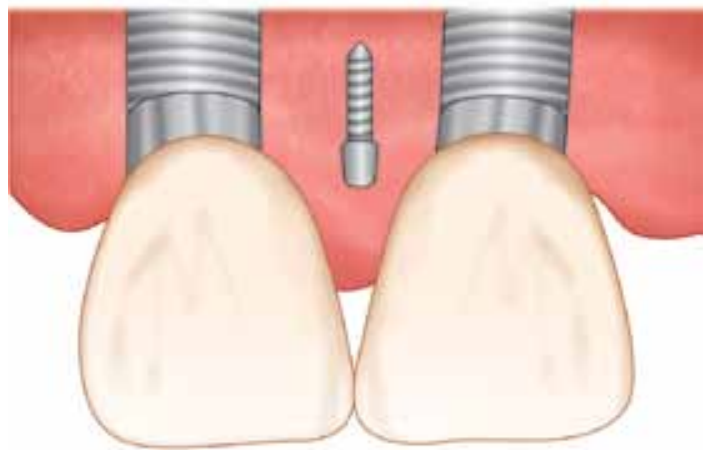

Fig. 12B: It creates a hard metal support for the tissue instead of bone. Soft tissue closure is achieved through relaxing incisions

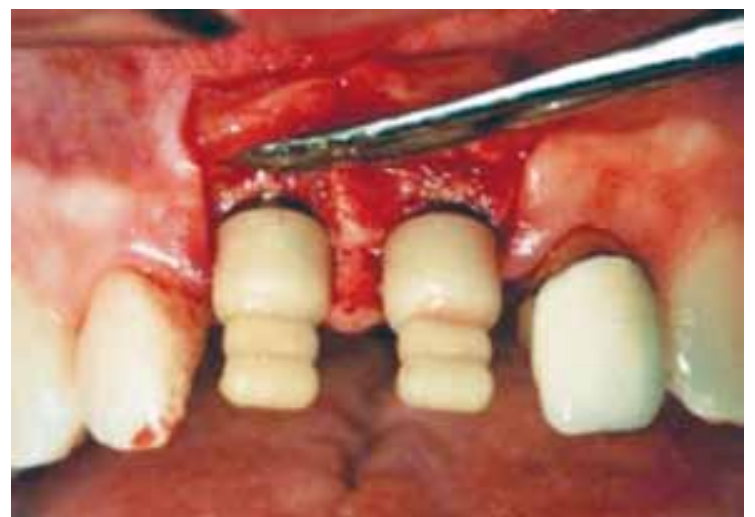

Fig.13B: The buccal flap is modified by creating a midline double pedicle flap

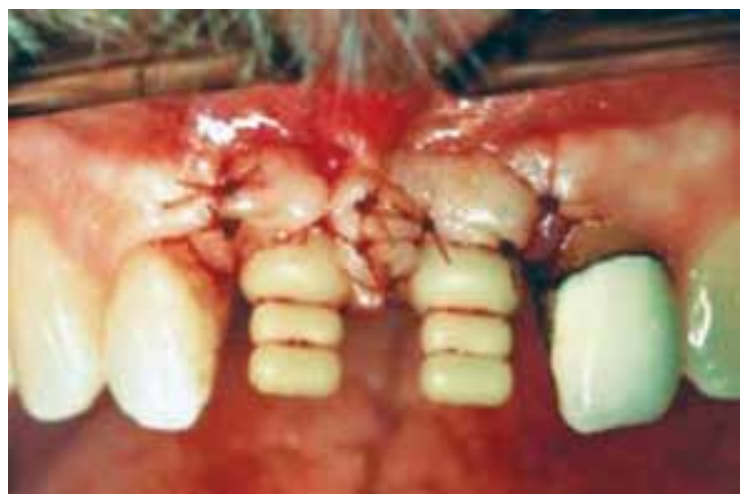

Fig.13C: Flap is mobilized to mesial and distal aspects of the implant and stabilized with sutures 
of template requires a space of not less than $3 \mathrm{~mm}$ between the two adjacent implants. After implants are inserted the interimplant bone is decorticated, to provide sufficient blood supply. The template is then placed on the ridge with its two perforated ends facing the alveolar ridge (Fig. 15B). After postoperative healing, the formation of the papilla like tissue is seen between the two implants (Fig. 15C). The long-term prognosis of this method is still under investigation and requires further assessment. ${ }^{17}$

\section{Technique by Rebaudi (2007) $)^{18}$}

This technique involves the transplantation of a full-thickness autogenous free gingival-bone graft obtained from the maxillary tuberosity in order to augment the interimplant papilla (Fig. 16A). Through a full-thickness buccal incision, a slight coronal elevation of the papilla can be achieved with small flap elevators. The free autogenous gingivalbone graft retrieved with a trephine bur can be modified in shape to obtain a wedge form (Fig. 16B). The wedge-form graft must be inserted across the buccal incision, under the interproximal papilla, elevating it coronally. The gingival part of the graft must be stabilized with a tight suture, leaving the epithelial portion of the graft exposed (Fig. 16C). The

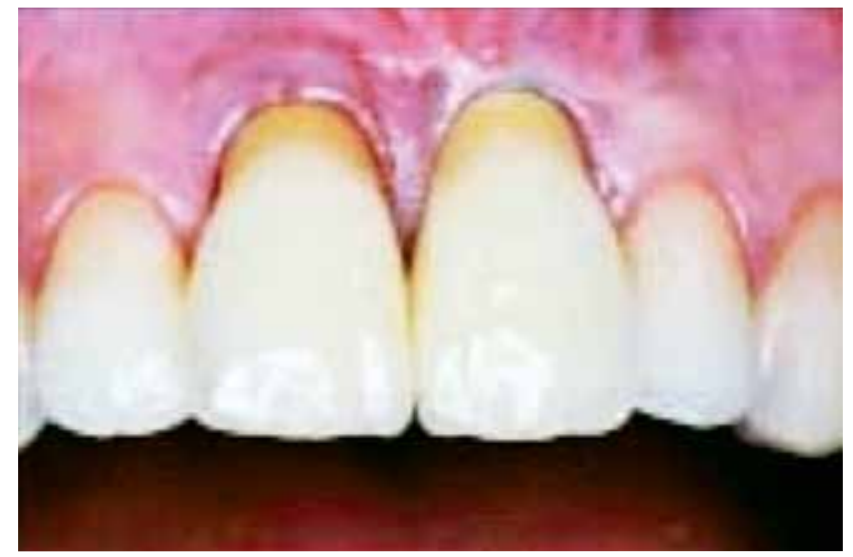

Fig.14A: Inadequacy of keratinized attached gingiva

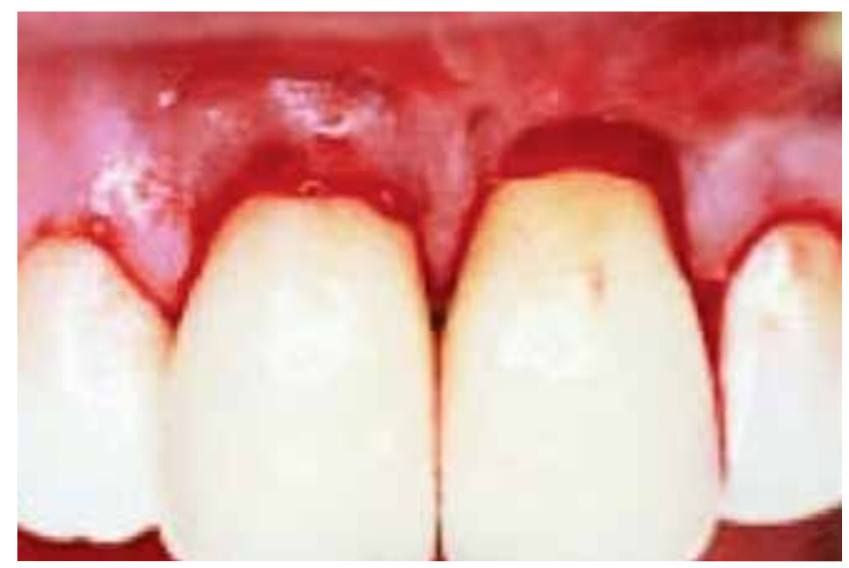

Fig.14B: The buccal flap is released from its insertion to the bone beyond the mucogingival junction complete regeneration of the interimplant papilla is seen (Fig. 16D). The advantages of the procedure are prevention of the gingival and bone resorption in the interdental area. The disadvantage of this procedure is the need to establish an intraoral donor site to obtain the gingival-bone graft and availability of a sufficient amount of bone and keratinized gingival tissue at a donor site.

\section{Omega-shaped Incision Technique by Bidra et al (2011) ${ }^{19}$}

This simple incision technique can be performed during the 1 st stage implant surgery. The proposed incision design is first plotted using the periodontal probe. After confirmation of the accuracy of the plotted design, a scalpel was used to create the incison along the plotted line. This incison design starts at the mesiobuccal sulcus of the tooth distal to the edentulous site and progressed to the edentulous site through the buccal sulcus to the mesial side before emerging at the middle of the crest of the ridge. From here, the incision is advanced by $5.5 \mathrm{~mm}$ before creating an omega-shaped and sparing a $4 \times$ $4 \mathrm{~mm}$ area of soft tissue at the crest of the soft at the crest (Fig. 17A). This intact area of soft tissue was hypothesized to promote formation of the papilla like tissue between two

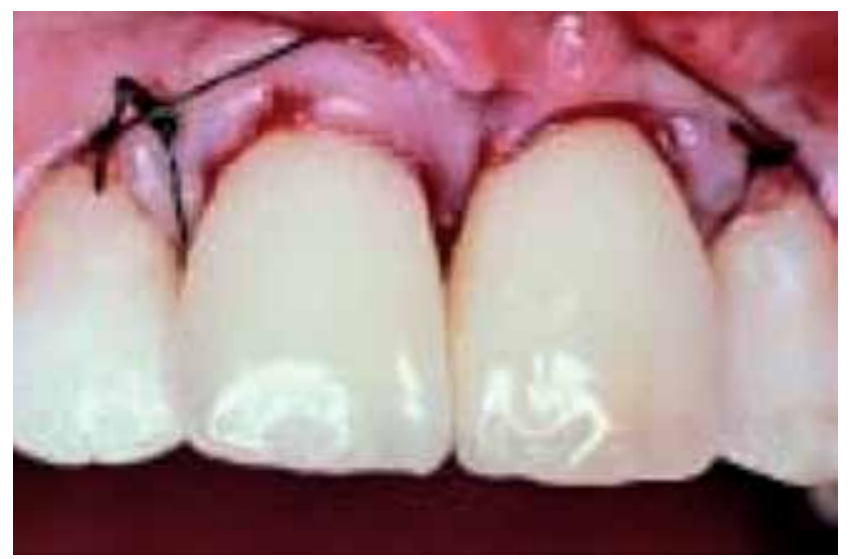

Fig.14C: The flap is coronally advanced and sutured

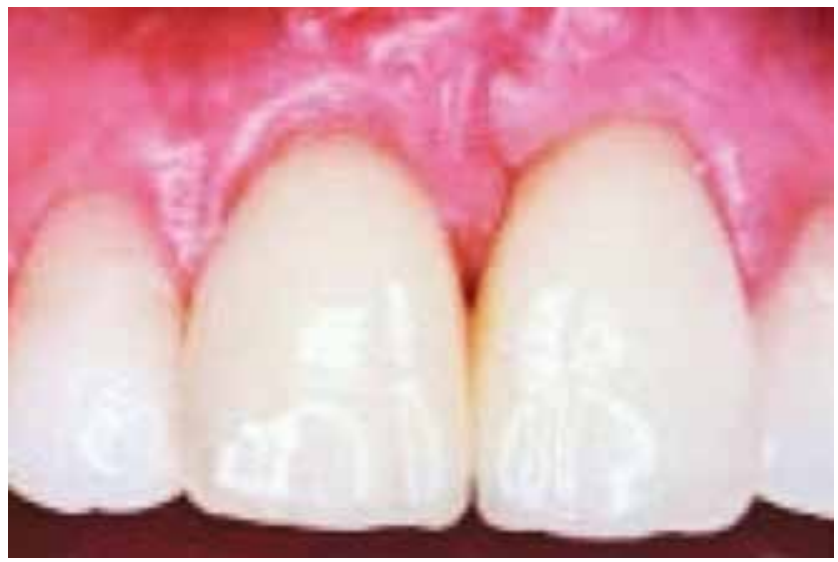

Fig.14D: The postoperative healing shows satisfactory results 
implants at a later stage. From here, the incision is advanced by $3.5 \mathrm{~mm}$ and a papilla sparing vertical release incision is performed. The incisions are retraced carefully and a full thickness mucoperiosteal flap is raised around the omegashaped area which is left intact (Fig. 17B). The crestal incision in the area of implant are excised and the placement of implants is carried out (Fig. 17C). Postoperatively, regeneration of the inter-implant papilla is seen (Fig. 17D). ${ }^{19}$

Other techniques are summarized in (Table 1).

\section{DISCUSSION}

The esthetic results are quite an important factor for successful restoration and establishment of intact papilla between implant and tooth or between adjacent implants, especially in the region of anterior maxilla. The level of interimplant papilla is influenced by the previous bone level, soft tissue quantity and quality, peri-implant biotypes, implant position and interimplant distance. ${ }^{20}$ Therefore, soft and hard tissue quality and quantity, peri-implant biotype, implant diameter, position and emergence profile should be considered with adequate treatment planning and evaluation of the surgical site prior to implant placement. ${ }^{20}$ However, the predictable regeneration of the interimplant papilla remains

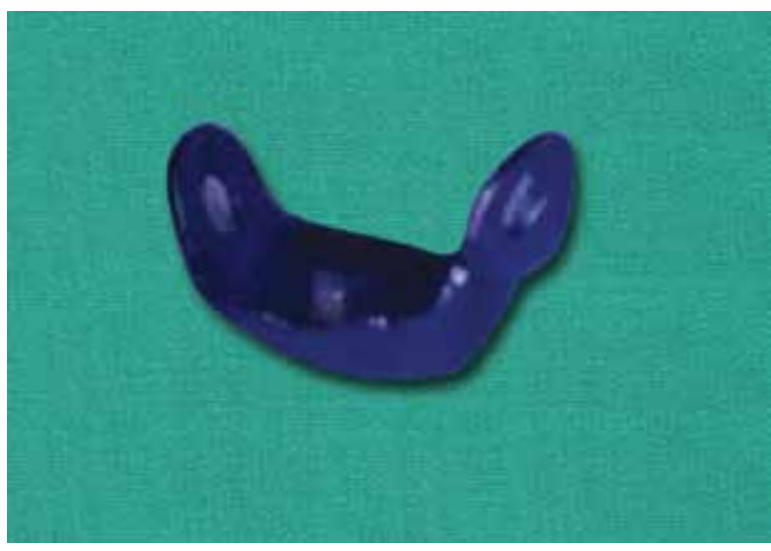

Fig.15A: Interimplant papilla regenerative template a complex challenge because most groups of supracrestal fibers do not exist in the gingival tissue surrounding the implant abutment and the blood supply of interimplant papilla is restricted ${ }^{21}$ due to the absence of the periodontal ligament and the associated blood vessel branches.

The presence of the interdental papilla between two teeth is directly related to the distance between the contact point and the interdental alveolar crest. ${ }^{22}$ These findings were confirmed by the classical study of Tarnow et al (1992) who correlated the presence or absence of interdental papilla with the distance between the bone crest and the contact point at 288 interproximal sites in 30 patients. They concluded that presence of the papilla was observed in almost $100 \%$ of the cases in which the distance was less than or equal to $5 \mathrm{~mm}$, in $56 \%$ of cases in which the distance was $6 \mathrm{~mm}$, and only $27 \%$ of cases in which the distance was $7 \mathrm{~mm}$ or more. ${ }^{22}$

Similar to natural teeth, resorption of the interimplant bone results in loss of interimplant papillae. However, to preserve the papilla in the case of single implants adjacent to natural teeth, it is important to keep the distance from the point of contact to the bone level of $5 \mathrm{~mm}$ or less. The distance from the adjacent natural tooth to the alveolar crest is more critical than that from the height of the contact

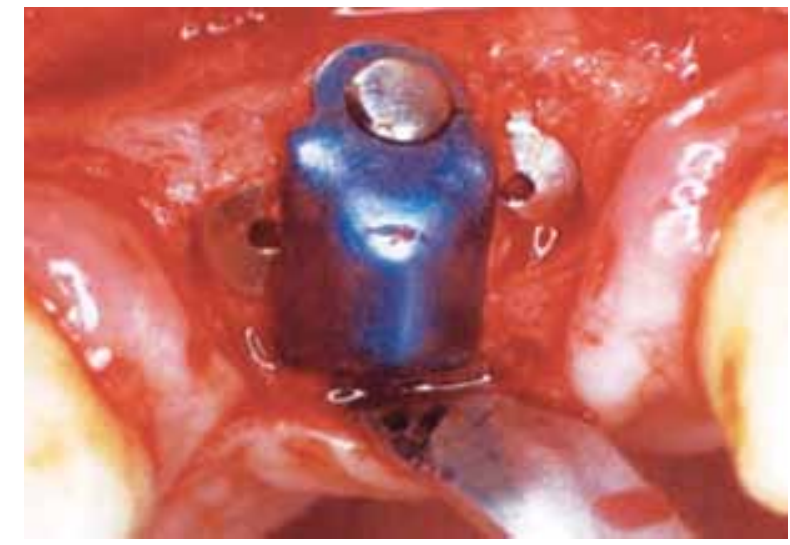

Fig.15B : The template is placed on the ridge with its two perforated ends facing the alveolar ridge

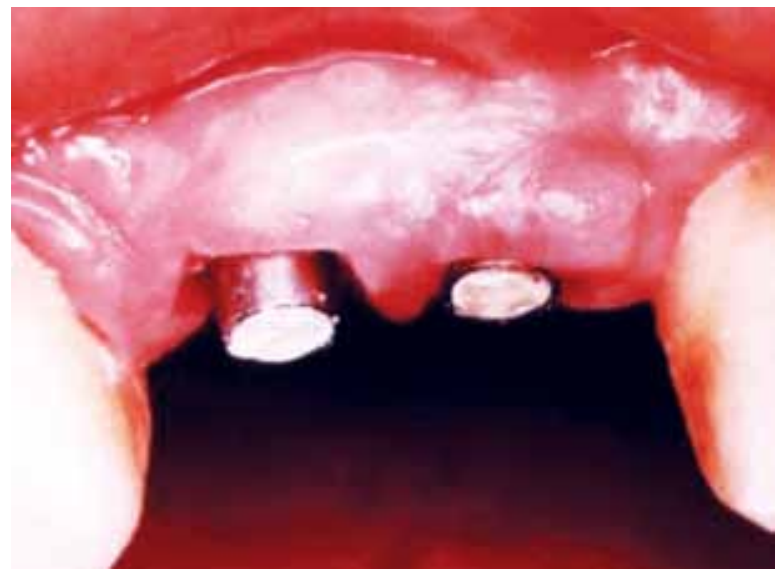

Fig.15C: After postoperative healing the formation of the papilla like tissue is seen between the two implants 


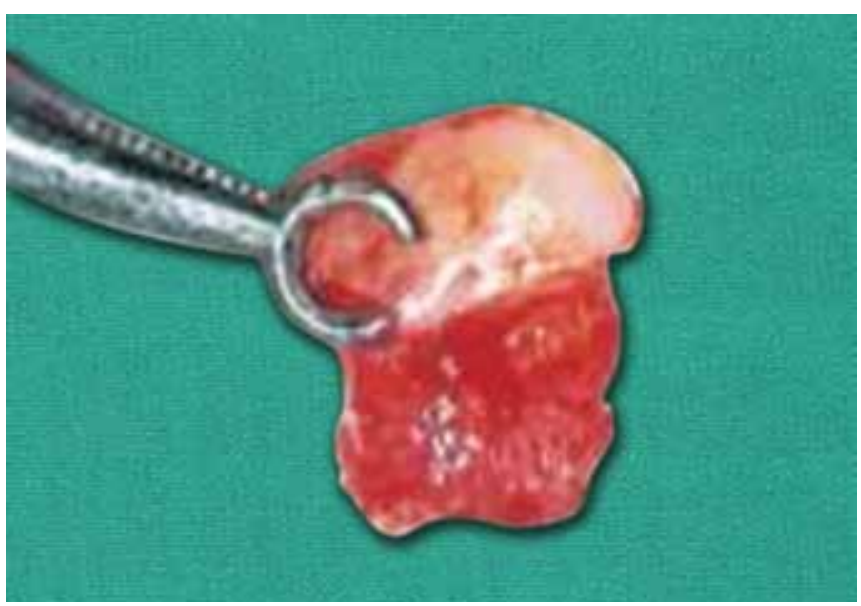

Fig. 16A: Full-thickness autogenous free gingival-bone graft obtained from the maxillary tuberosity

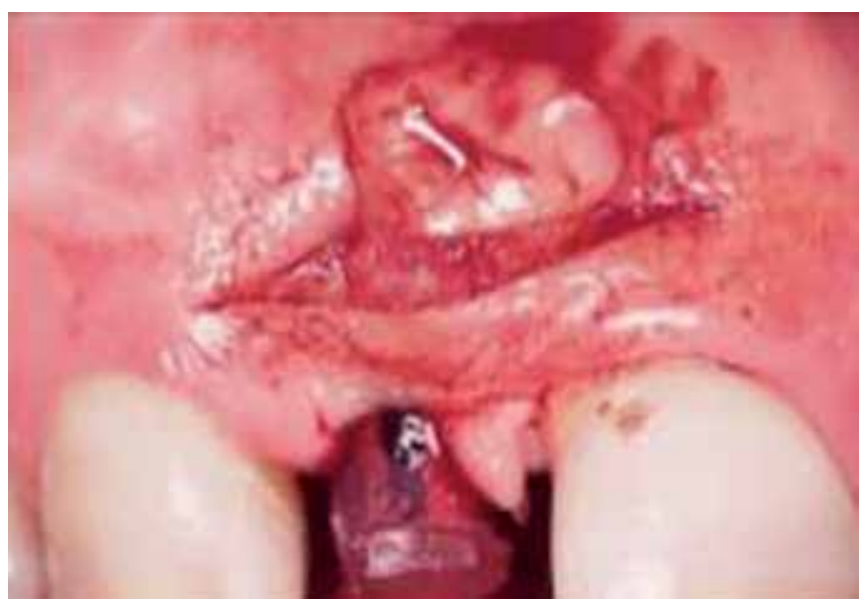

Fig. 16C: The gingival part of the graft must be stabilized with a tight suture, leaving the epithelial portion of the graft exposed

point of the implant to the bone. ${ }^{23}$ The interdental papillary recession is more pronounced when two implants are placed adjacent to each other and hence to prevent bone loss and thereby the papilla loss, it is important that the mesiodistal distance between the two implants is of $3 \mathrm{~mm}^{23}$

The surgical technique described by Palacci ${ }^{1}$ uses the bevelled incisions in the mobile flap which should be delicate and vary according to needs (thickness, height or both), the rotated pedicles should be tension-free and the suturing technique should provide a tight and firm connection of the pedicles to the supporting bone and abutments. The technique by Nemcovsky has the advantage is that it is relatively easy to perform. Although, this technique is not indicated when apical repositioning of the mucogingival junction is needed due to inadequacy of buccal attached masticatory mucosa. ${ }^{8}$ The results of the Grossberg's technique showed an average loss of $0.5 \mathrm{~mm}$ of soft tissue height when modified flap technique is carried out at the time of abutment connection. The interimplant papilla regenerative template offers various advantages, such as it is placed at the time of implant placement hence rules out the need of a

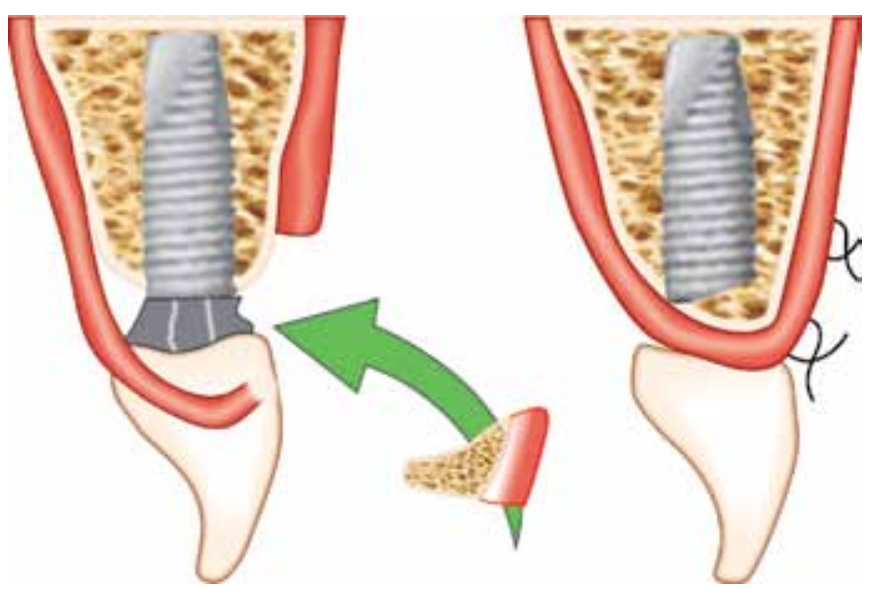

Fig. 16B: The free autogenous gingival-bone graft modified in wedge shape

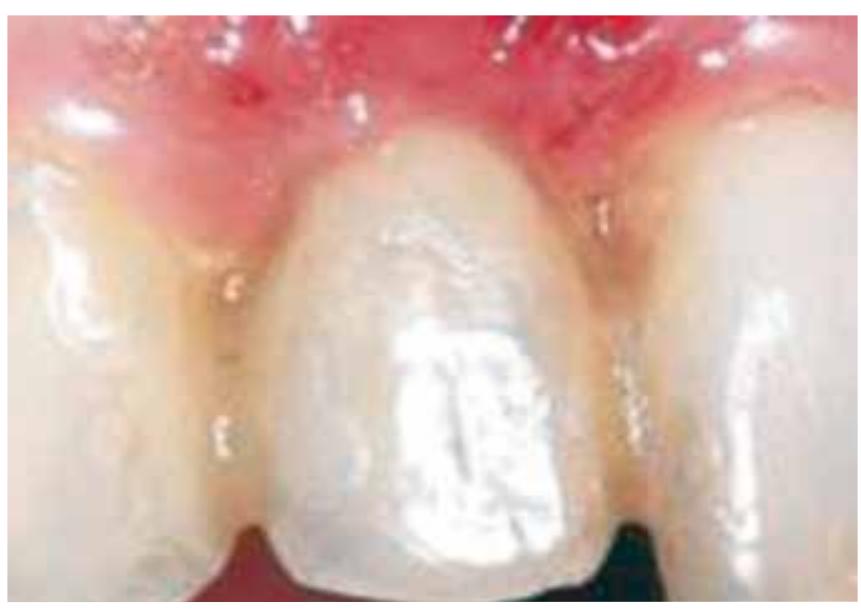

Fig.16D : The complete regeneration of the inter-implant papilla

second surgery. ${ }^{17}$ The template carries and protects the bone graft material and also separated the bone-graft mix from undesired fibroblasts and epithelial cells which favors graft predictability. ${ }^{17}$ The technique described by Rebaudi used the autogenous free gingival-bone graft technique which allows for easier retrieval of a graft and its secure stabilization in the prepared site and provide the primary seal. Very fast healing and integration of the graft were seen clinically and confirmed by histologic results. The fast healing of the graft is useful because it reduces the time needed to obtain gingival and bone augmentation for implant placement or papilla reconstruction and allows earlier functional loading of implants. The hypothesis for the omega incision technique was that a small area of soft tissue from surgical insult has less shrinkage as compared with adjacent tissue and lends itself to be contoured to a papilla-like tissue by further restorations.

Four potential time points can be differentiated for soft and/or hard tissue management: prior to implant placement; at time of placement or during the healing phase of the implant; at second-stage surgery and in the maintenance. Various surgical techniques have been suggested to 
reconstruct interimplant papilla at the time of second stage implant surgery, but comparison of efficacy among techniques or long-term results is still insufficient, and the procedure is not predictable.

\section{CONCLUSION}

From a clinical standpoint of view, the reconstruction of the interimplant papilla is one of the most difficult, challenging and unpredictable procedures in periodontal plastic surgery. The soft tissue histological characteristics of interimplant and interdental papillae are similar, except that interimplant papillae have a connective tissue fiber orientation, have a higher percentage of collagen fiber with fewer fibroblasts, and attain a less adequate blood supply because of the periodontal ligament. This makes the interimplant papillae more like scar tissue, which may complicate any attempts for surgical repair or reconstruction. Clinicians from different disciplines have described various treatment plans and techniques to restore the deficient papilla, but none of them seem to be sufficient to regain the lost interproximal papilla

Table 1: Summary of other techniques for reconstruction of interimplant papilla

\begin{tabular}{ll}
\hline Technique & Summary \\
\hline $\begin{array}{l}\text { Price and Price } \\
(1999)^{2}\end{array}$ & $\begin{array}{l}\text { Vertical releasing incisions are placed raising a full thickness flap. A connective tissue graft is placed sub- } \\
\text { epithelially and secured with mattress sutures. After a month, the connective tissue and the flap are coronally } \\
\text { advanced to the level of gingival margin of the adjacent tooth. }\end{array}$ \\
$\begin{array}{l}\text { Tinti and Benfenati } \\
(2002)^{2}\end{array}$ & $\begin{array}{l}\text { A ramp mattress suture is used to obtain a papilla between two implants in the buccal area. By this technique, } \\
\text { the buccal flap will receive coronal pulling traction. }\end{array}$ \\
Misch et al (2004) & $\begin{array}{l}\text { Three interlacing finger-like incisions are made over and adjacent to each implant site, and a sulcular incision is } \\
\text { made extending } 2 \text { to } 3 \text { mm to the palatal side. Facial 'fingers' are elevated to the desired interimplant height for } \\
\text { papillae. The idle 'palatal finger' is then split and reflected to the respective mesial and distal sides and sutured } \\
\text { instead of using modified vertical mattress sutures. }\end{array}$ \\
Lee et al (2010) & $\begin{array}{l}\text { A horizontal incision was also performed, parallel to the buccal side, on the palatal side, which was in contact } \\
\text { with the palatal border line of the implant different from the labial side. Another incision was done buccolingually } \\
\text { over the implant midline perpendicular to the horizontal incision lines performed on the labial and palatal sides. } \\
\text { As a consequence, the final incision line became l-shaped. The healing abutment has been connected and both } \\
\text { flaps were folded up alongside the healing abutment intending them to heal without suture. }\end{array}$ \\
\hline
\end{tabular}

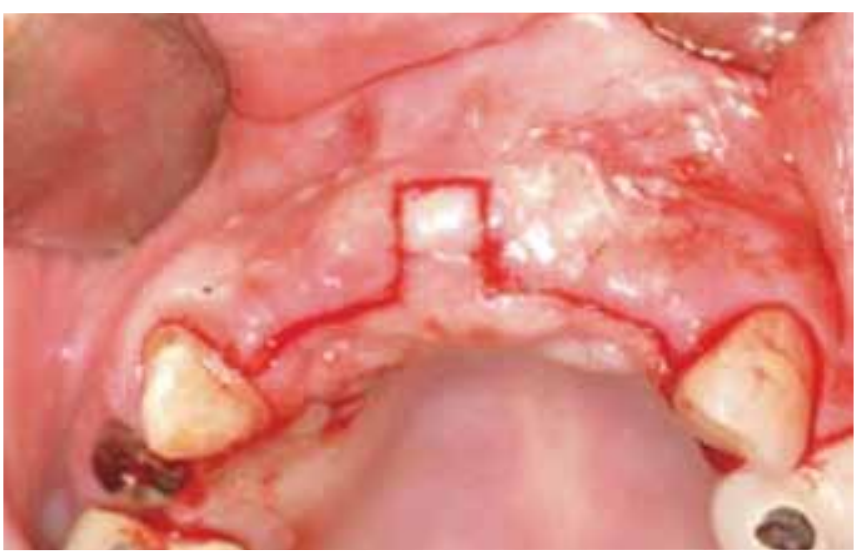

Fig.17A: The omega shaped incision

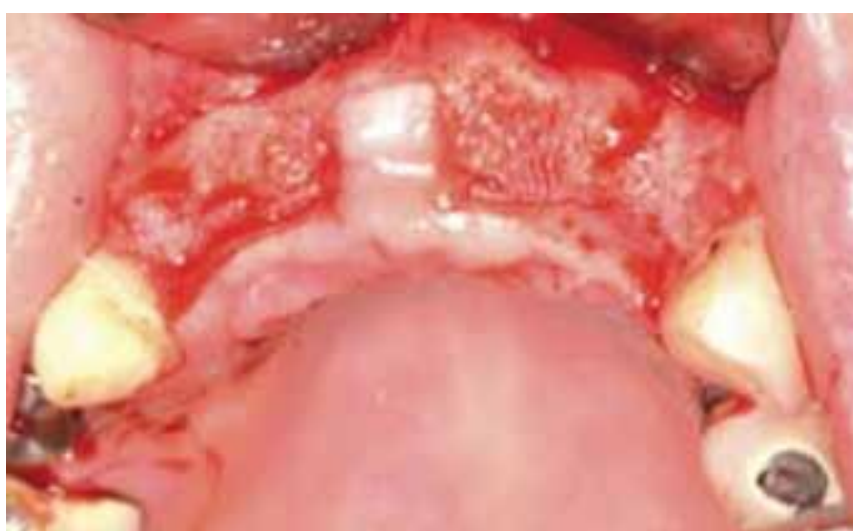

Fig.17B: The full thickness mucoperiosteal flap is raised around the omega shaped area which is left intact

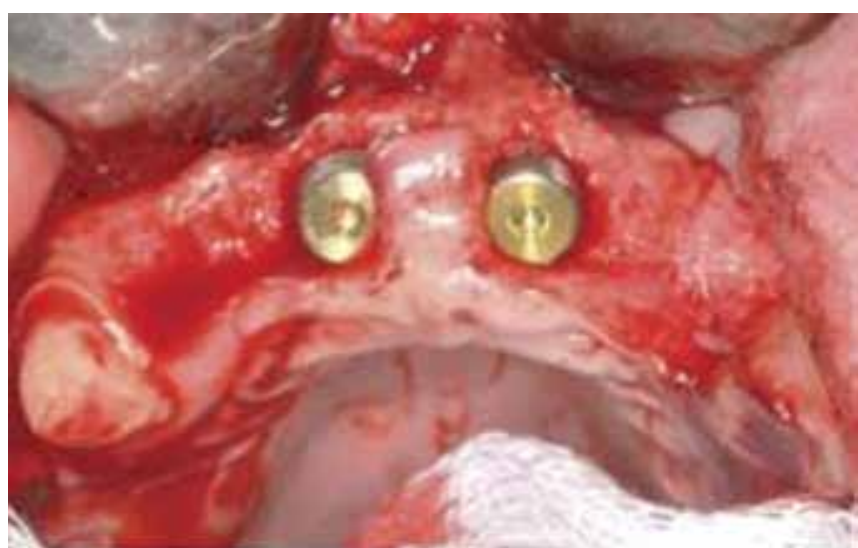

Fig.17C: The crestal incision in the area of implant are excised; placement of implants is carried out

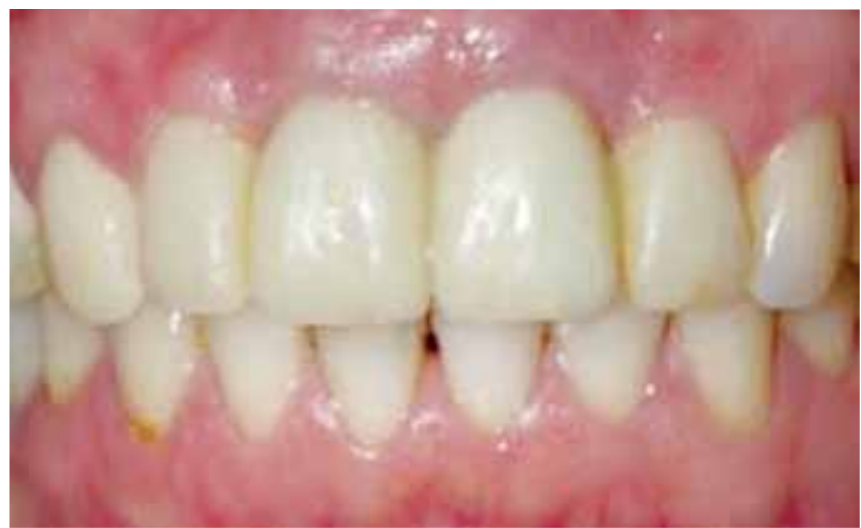

Fig.17D: Regeneration of the inter-implant papilla seen postoperatively 
completely and predictably. Since no long-term studies have been conducted, no particular technique is recommended over other. In the near future, with the development of newer implant designs and innovations in surgical techniques, it may be possible to achieve more predictable results than present.

\section{REFERENCES}

1. Palacci P, Nowzari H. Soft tissue enhancement around dental implants. Periodontology 2000. 2008;47(1):113-132.

2. Pradeep AR, Karthikeyen B. Periimplant papilla reconstruction: realities and limitations. J Periodontol 2006;77:53-44.

3. Zetu L, Wang H-L. Management of inter-dental/inter-implant papilla. J Clin Periodontol 2005;32:831-839.

4. Bergstrom J. The topography of papillary gingiva in health and early gingivitis. Journal of Clinical Periodontology 1984:2: 423-431.

5. Shapiro A. Regeneration of interdental papillae using periodic curettage. Int J Periodont Rest Dent 1985;5(5):27-33.

6. Beagle JR. Surgical reconstruction of the interdental papilla: case report. Int J Periodontics Restorative Dent 1992;12:145-151.

7. Abrams L. Augmentation of the deformed residual edentulous ridge for fixed prosthesis. Compend Contin Educ Dent 1980; 1:205-213.

8. Evian CI, Corn H, Rosenberg ES. Retained interdental papilla procedure for maintaining anterior esthetics. Compend Contin Educ Dent 1985;6:58-64.

9. Han TJ, Takei HH. Progress in gingival papilla reconstruction. Periodontol 2000, 1996;11:65-68.

10. Tarnow DP. Semilunar coronally repositioned flap. J Clin Periodontol 1986;13:182-185.

11. Kokich VG. Excellence in finishing: modifications for the periorestorative patient. Semin Orthod 2003;9:184-203.
12. Cohen E. Atlas of cosmetic and reconstructive periodontal surgery. 3rd ed. Hamilton: BC Deker Inc 2006.

13. Nemcovsky CE, Moses O, Artzi Z. Interproximal papilla reconstruction in maxillary implants. J Periodontol 2000;71: 308-314.

14. El Salam El Askary A. Use of titanium papillary insert for construction of interimplant papillae. Implant Dent 2000;9:358362.

15. Grossberg D. Interimplant papilla reconstruction: assessment of soft tissue changes and results of 12 consecutive cases. J Periodontol 2001;72:958-962.

16. Azzi, et al. Surgical thickening of the existing gingiva and reconstruction of interdental papillae around implant-supported restorations. Int J Periodontics Restorative Dent 2002;22: 71-77.

17. El Salam El AskaryA. Reconstructive aesthetic implant surgery. Wiley and Sons 2003.

18. Rebaudi, et al. A new technique for bone augmentation and papilla reconstruction with autogenous free gingival-bone grafts. Int J Periodontics Restorative Dent 2007;27:429-439.

19. Bidra AS, Rungruanganunt P. Omega-shaped $(\Omega)$ incision design to enhance gingival esthetics for adjacent implant placement in the anterior region. J Oral Maxillofac Surg 2011 Aug;69(8): 2144-2151.

20. Lee, et al. I-shaped incisions for papilla reconstruction in second stage implant surgery. J Periodontal Implant Sci 2010;40: 139-143.

21. Berglundh T, Lindhe J, Jonsson K, Ericsson I. The topography of the vascular systems in the periodontal and peri-implant tissues in the dog. J Clin Periodontol 1994;21:189-193.

22. Tarnow, et al. A classification system for loss of papillary height. J Periodontol 1998;69:1124-1126.

23. Oliveria, et al. Papillary regeneration: anatomical aspects and treatment approaches. RSBO 2012 Oct-Dec;9(4):448-456. 